Atmos. Chem. Phys. Discuss., 10, 23627-23656, 2010

www.atmos-chem-phys-discuss.net/10/23627/2010/

doi:10.5194/acpd-10-23627-2010

(c) Author(s) 2010. CC Attribution 3.0 License.

\title{
A simplified empirical method for determination of aerosol hygroscopicity and composition
}

C. H. Chan ${ }^{1}$, A. Y. S. Cheng ${ }^{2,3}$, and A. Viseu ${ }^{1}$

${ }^{1}$ Meteorological and Geophysical Bureau, Rampa do Observatório, Taipa Grande, Macao, China

${ }^{2}$ Macau University of Science and Technology, Avenida Wai Long, Taipa, Macao, China

${ }^{3}$ Sichuan University, 29 Wangjiang Road, Chengdu 610064, China

Received: 27 May 2010 - Accepted: 6 September 2010 - Published: 12 October 2010

Correspondence to: A. Y. S. Cheng (ayscheng@ netvigator.com)

Published by Copernicus Publications on behalf of the European Geosciences Union.

Determination of aerosol

hygroscopicity and composition

C. H. Chan et al.

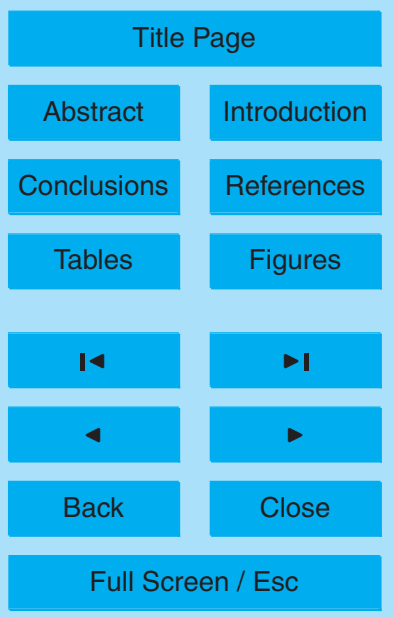

Printer-friendly Version

Interactive Discussion 


\section{Abstract}

Atmospheric aerosols have substantial influence on the Earth's radiation budget, visibility, cloud formation and precipitation. The aerosol hygroscopicity and the composition of aerosols are of vital importance for solar radiation budget calculation, cloud formation

5 mechanism, and measurement of aerosol spatiotemporal distribution through remote sensing, such as Lidar, MODIS and sun/star photometer. In this paper, hourly averaged records of humidity, visibility and aerosol concentration, conducted in Macao, P.R.C. from 1 February 2006 to 31 December 2008 (LT), are used to estimate aerosol hygroscopicity and composition with a simplified empirical method. The result of monthly variation of aerosol hygroscopicity indicates the important role of aerosol composition on optical properties, which is in agreement with the previous study. This aerosol composition pattern is also consistent with the Asiatic Monsoon pattern and vicinity, such as Hong Kong. The monthly variation of aerosol hygroscopicity and composition also shows the necessity to consider such a factor for the aerosols monitoring by remote system and aerosols forcing simulated by climate model.

\section{Introduction}

Aerosol is important in the atmospheric processes as it can modify the Earth's radiation budget (Charlson et al., 1992; Schulz et al., 2006) and affects both cloud (Twomey, 1977; Charlson et al., 2001) and precipitation formations (Rosenfeld et al., 2007; Jones et al., 2010), and vertical cloud particle growth (Suzuki et al., 2008). In particular, aerosol through the scattering process can alter regional visibility (Wu et al., 2005; Deng et al., 2008; Molnár et al., 2008). Furthermore, black carbon also affects regional atmospheric stability through the radiation absorption process (Menon et al., 2002).

The impact of aerosols on the solar radiation budget is direct by absorption and 25 scattering (Ramanathan et al., 2001). The direct climate forcing is sensitive to aerosol composition, size distribution, and relative humidity which is the single most important

\section{Determination of aerosol \\ hygroscopicity and composition}

C. H. Chan et al.

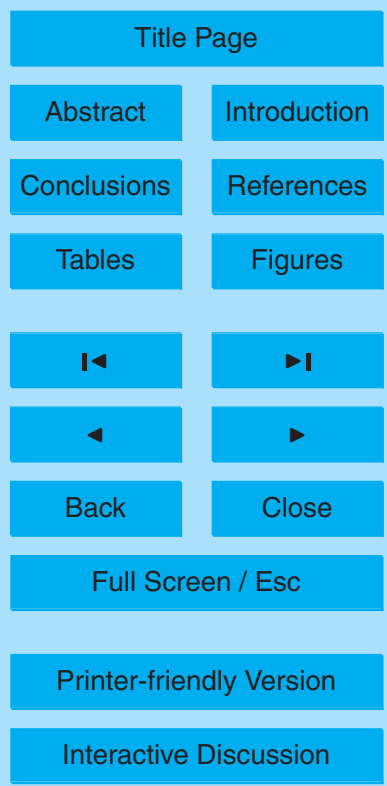


parameter (Pilinis et al., 1995). Atmospheric pollution alters the radiation budget through increasing thin cloud albedo and, hence, overall planetary albedo indirectly (Twomey, 1977). However, aerosols, with moderate or strong absorption, heat the lower atmosphere and stabilize the atmosphere. The reduction in cloud fraction, by 5 absorbing aerosols, may represent one of the mechanisms contributing to the global warming despite the aerosol cooling effect (Fan et al., 2008). In addition, the magnitude of aerosol forcing is still in question due to the inconsistency between forward calculation and inverse calculation (Anderson et al., 2003).

In order to study climate forcing due to atmospheric aerosols, it is necessary to study 10 the information on aerosol loading and optical properties, such as aerosol optical depth $(A O D)$, aerosol extinction coefficient $(\sigma)$, and aerosol single scattering albedo (SSA; the ratio of incident radiation scattered to total extinction). Previous studies (Covert et al., 1972; Pilinis et al., 1995; Buzorius et al., 2002; Carrico et al., 2003; Baynard et al., 2006; Yoon et al., 2006; Massling et al., 2007; Eichler et al., 2008; Liu et al., 2008) 15 have led to the knowledge on highly dependent optical properties on the relative humidity $(\mathrm{RH})$ condition over ambient air. Pilinis et al. (1995) suggested that an increase of the relative humidity from 40 to $80 \%$ will result in an increase of the radiative forcing of global mean aerosol by a factor of 2.1. From the aerosol optical and radiative transfer modelling studies, Yoon et al. (2006) found that the diurnal-averaged aerosol radiative forcing efficiency (defined as radiative forcing per unit AOD) at the surface, top of the atmosphere (TOA), and atmosphere were decreased with increasing $\mathrm{RH}$ because the increasing rate of aerosol optical depth with $\mathrm{RH}$ is greater than the increasing rate of aerosol radiative forcing with $\mathrm{RH}$. These hygroscopic properties of aerosols influence ambient particle size distribution, density and mass (Covert et al., 1972; Pilinis et al., 25 1995; Massling et al., 2007) which in turn control the lifetime and removal mechanism of aerosols. In addition, the hygroscopic growth will result in changes of particle shape and refractive index of aerosol (Covert et al., 1972). These hygroscopic properties and compositions of aerosols also affect the measurement of atmospheric optical properties, such as Atmospheric Optical Depth and aerosol extinction coefficient, during

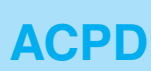

10, 23627-23656, 2010

\section{Determination of aerosol \\ hygroscopicity and composition}

C. H. Chan et al.

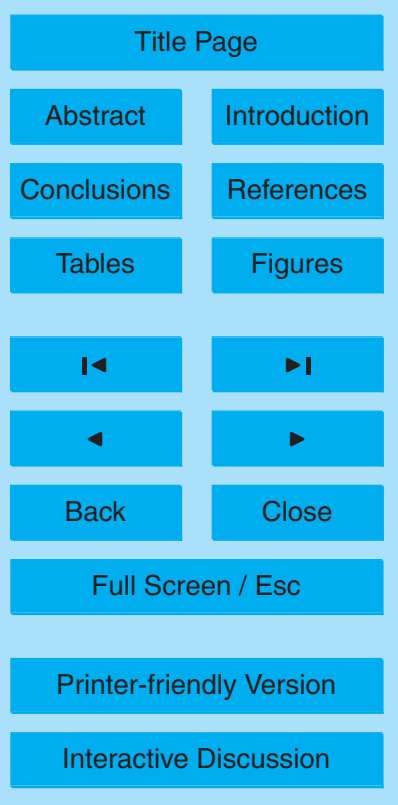


remote sensing (e.g. Lidar, MODIS, sun/star photometer) (Li et al., 2005; Kim et al., 2007; Kondragunta et al., 2008). Furthermore, there is a suggestion that the highly nonlinear relationship between $\mathrm{RH}$ and the aerosol mass extinction efficiency at high $\mathrm{RH}(>80 \%)$ affect AOD simulation (Bian et al., 2009).

5 However, the composition of aerosols over the world has obvious spatial and temporal variability related to source and season. D'Almeida et al. (1991) integrated previous surveys and concept models to establish a series of aerosol models and their hygroscopic properties. In order to obtain more detailed information on aerosols over Pearl River Delta (PRD), Wang et al. (2008) organized the aircraft measurements to 10 obtain the concentration and vertical distribution characteristics of particulate matter during the Program of Regional Integrated Experiments of Air Quality over Pearl River Delta 2004 (PRIDE-PRD2004). In addition, in situ measurements, HTDMA-system (Hygroscopicity/Humidified-Tandem Differential Mobility Analyzer) is always used to investigate the hygroscopic growth related to the sized change of certain particles under 15 different $\mathrm{RH}$ conditions (Buzorius et al., 2002; Massling et al., 2007). The individual particle chemical composition analysis is also done by the Single Particle Laser Ablation Time-of-flight Mass Spectrometer (SPLAT-MS) (Buzorius et al., 2002). Those in situ measurements will make an important contribution to the estimation of aerosols radiative forcing especially region forcing.

20 However, it is very difficult to carry out these measurements of the physical, chemical and optical properties of aerosols over a long period and in every region because of necessary huge resources. Therefore, it is more practical to try using a mathematic method to estimate the effect of hygroscopic growth and related chemistry compositions, and this kind of study is limited. Hänel (Hänel, 1984; Uhlig et al., 1994) established a relationship to convert the aerosol extinction coefficient $(\sigma)$ into the aerosol extinction coefficient corresponding to a dry situation ( $\mathrm{RH}$ is equal to zero) on an average condition. D'Almeida et al. (1991) integrated different surveys and concept models to build the relationship between aerosol extinction coefficient $(\sigma)$ and dry aerosol extinction coefficient $\left(\sigma_{0}\right)$ under different original sources. Cheng et al. (2004) indicated

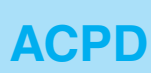

10, 23627-23656, 2010

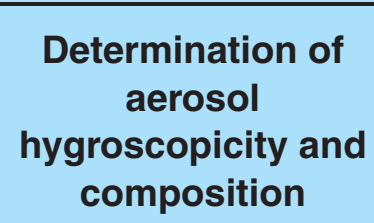

C. H. Chan et al.

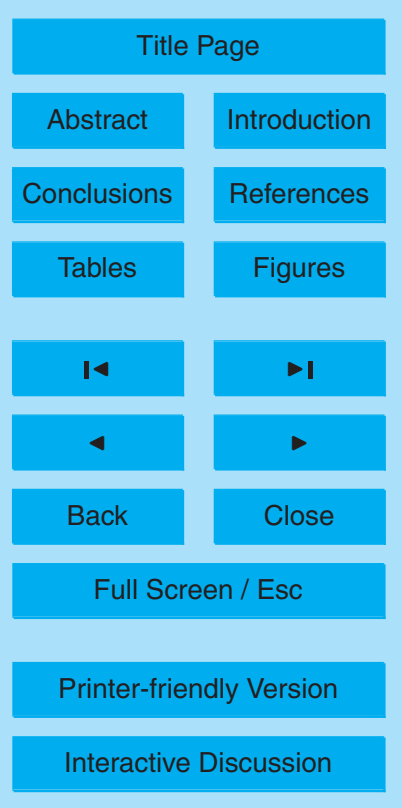


that a combination of shape function, which is based on D'Almeida et al. (1991) results, could be established to simulate the effect of airborne particle mixture on hygroscopic properties.

In this paper, Hänel (1984) (Method I) and Cheng et al. (2004) methods (Method II) 5 will be used to describe the hygroscopic properties. Furthermore, the composition of aerosols will be analyzed by Method II for the data obtained in Macao. Section 2 describes the location, measurement instruments, and synoptic-scale meteorological characteristics. The methodology will be introduced in Sect. 3 with results discussed in Sect. 4. Finally, Sect. 5 gives the conclusion.

\section{Description of location}

Macao Special Administrative Region (Macao SAR), which is located in the western part of the Pearl River Delta (PRD), includes a peninsula(Macao Peninsula, $9.3 \mathrm{~km}^{2}$ ), two main islands (Taipa, $6.7 \mathrm{~km}^{2}$; Coloane, $7.6 \mathrm{~km}^{2}$ ) and a reclamation zone (CoTai reclamation zone, between Taipa and Coloane, $5.6 \mathrm{~km}^{2}$ ) with a total area of $29.2 \mathrm{~km}^{2}$.

15 It is one of the perfect crossroads for the meeting of East and West cultures during past several centuries, and the Historic Centre of Macau was inscribed as a World Heritage Site, at the 29th Session of the World Heritage Committee hosted by the United Nations Educational, Scientific and Cultural Organization (UNESCO). However, air pollution issues due to fast economic development and intense human activity deeply threaten the historical and cultural city, Macao.

In order to monitor the air pollutants, Meteorological and Geophysical Bureau (SMG) established an automatic network including five stations to monitor and record the air pollution concentrations, namely $\mathrm{PM}_{10}, \mathrm{PM}_{2.5}, \mathrm{NO}_{2}, \mathrm{SO}_{2}, \mathrm{O}_{3}$, and $\mathrm{CO}$. The hourly averaged measurement, including visibility, relative humidity and PM concentration, in this paper was all conducted at the Macao SMG station, located in Taipa Grande (114 m above sea level) from 1 February 2006 to 31 December 2008 (LT). PM 10 and $\mathrm{PM}_{2.5}$ samples were all measured by TEOM series $1400 \mathrm{a}$ ambient particulate monitor

\section{Determination of aerosol hygroscopicity and composition}

C. H. Chan et al.

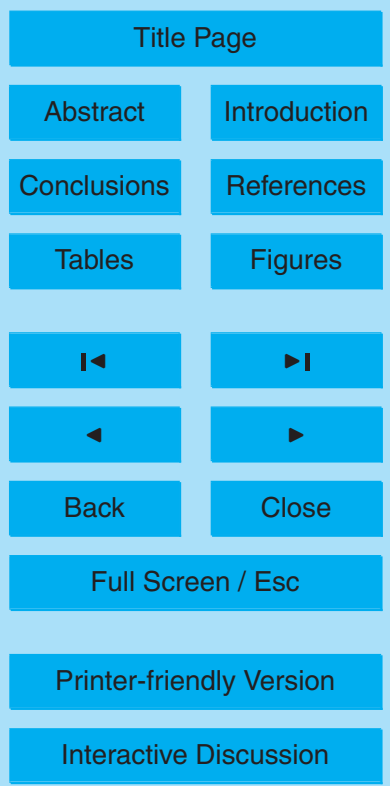


(Rupprecht \& Patashnick, Albany, NY, USA) with Rupprecht \& Patashnick PM-2.5 and PM-10 Inlet. Humidity and Visibility were taken by Vaisala HUMICAP® 180 Sensor and Vaisala Visibility Metre FD12 (FD12), respectively.

Synoptic-scale meteorology in Macao is influenced by the Asiatic Monsoon. Spring 5 is characterised by predominant easterly winds. A low-pressure trough draws moist warm air mass inland from the ocean during summer, resulting in southwesterly to southeasterly winds. During autumn, the winds become stronger and east or northeasterly. Strong radiative cooling over the continent creates a high-pressure anticyclone that drives cold and dry polar air mass from the continent into the surrounding 10 oceanic areas during winter, the winds becomes weak to moderate northeasterly winds or strong northerlies. Finally, different aerosol and air mass (warm, wet and maritime during summer; cold, dry and continental during winter) will be transported to Macao and its vicinity under this Asiatic Monsoon pattern.

\section{Methodology}

15 In this paper, the aerosol hygroscopicity and composition, marked by their unique chemical and microphysical property, are regressed from the atmospheric visibility, relative humidity $(\mathrm{RH})$ and aerosol concentration.

The extinction coefficient $(\sigma)$ can be inverted using the following relationship between visibility $V_{\mathrm{m}}$ at the middle of visible range $(0.55 \mu \mathrm{m})$ and $\sigma$ (Hinkley, 1976).

${ }_{20} \quad V_{\mathrm{m}}=\frac{3.91}{\sigma}\left(\frac{0.55}{\lambda}\right)^{q}$

Where $q=1.3$ for average seeing conditions. $V_{\mathrm{m}}$ is the visibility $(\mathrm{km})$ and recorded by Vaisala Visibility Meter FD12. $\lambda$ is wavelength, and is set to $0.55(\mu \mathrm{m})$, which is similar to the wavelength of our elastic Mie scattering Lidar system $(0.532 \mu \mathrm{m})$ (Tam et al., 2008). The total light extinction is only assumed to be contributed by scattering (SSA is equal to one) to simplify calculation. Since the extinction of $0.012 \mathrm{~km}^{-1}$ due

\section{Determination of aerosol \\ hygroscopicity and composition}

C. H. Chan et al.

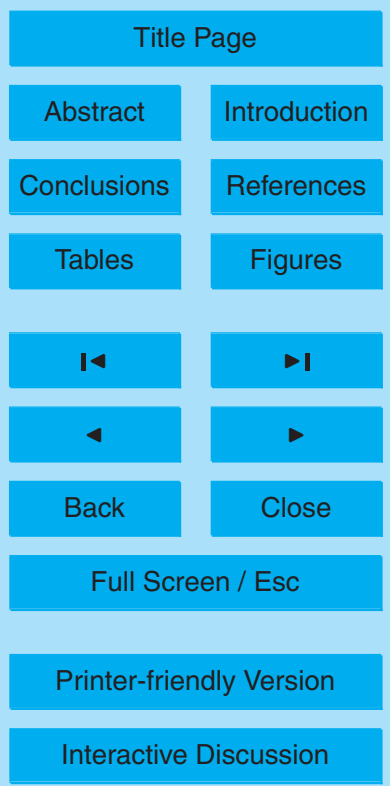


to Rayleigh scattering is included in the total extinction, a correction will also be applied to remove the Rayleigh (gaseous) scattering extinction. Therefore, the extinction coefficient, hereafter, is the aerosol scattering extinction coefficient.

In order to show the impact of humidity on the extinction and make a comparison 5 with Method I, Method II developed by Hänel (Hänel, 1984; Uhlig et al., 1994) is used to eliminate the dependence of the extinction coefficient $(\sigma)$ on relative humidity, by converting the aerosol extinction coefficient $\sigma(\mathrm{RH})$ into the dry aerosol extinction coefficient $\left(\sigma_{0}\right)$ corresponding to $\mathrm{RH}=0$.

$$
\frac{\sigma(\mathrm{RH})}{\sigma_{0}}=f(\mathrm{RH})
$$

$$
\begin{aligned}
\text { Method I: } & (1-\mathrm{RH})^{-r} \text { when } 0 \leq \mathrm{RH} \leq 0.7 \\
& \text { or }=a_{\mathrm{E}} \bullet(1-\mathrm{RH})^{-b_{\mathrm{E}}} \text { when } 0.7 \leq \mathrm{RH} \leq 0.999
\end{aligned}
$$

With $r=b_{\mathrm{E}}-\ln \left(a_{\mathrm{E}} / 0.3\right), b_{\mathrm{E}}=0.7585, a_{\mathrm{E}}=0.6648, \mathrm{RH}$ is relative humidity. Equation (2) shows that dry aerosol extinction can be calculated by aerosol extinction and $\mathrm{RH}$. In addition, the monthly variation of the ratio $\left(Y_{0}\right)$ of aerosols extinction coefficient in dry condition $\left(\sigma_{0}\right)$ to aerosols concentration is also calculated to compare results from Method II (Cheng et al., 2004).

D'Almeida et al. (1991) integrated previous surveys and concept models to establish a series of aerosol models which consists of Arctic aerosol, Antarctic aerosol, desert aerosol, clean continental aerosol, clean forest aerosol, average continental aerosol, urban aerosol, clean maritime aerosol, maritime mineral aerosol, and maritime polluted aerosol. Each model represents a specific hygroscopic growth property related to the particular microphysical and chemical composition. Their proportions in the air are continuously changing and affected by different meteorological variables such as the characteristics of the air mass. After considering the situation in Macao and PRD, six basic aerosol components will be used below:

1. Average continental aerosol (ac): slightly influenced by industrial activity, traffic and other anthropogenic activities that lead to aerosol emission.

\section{Determination of aerosol \\ hygroscopicity and composition}

C. H. Chan et al.

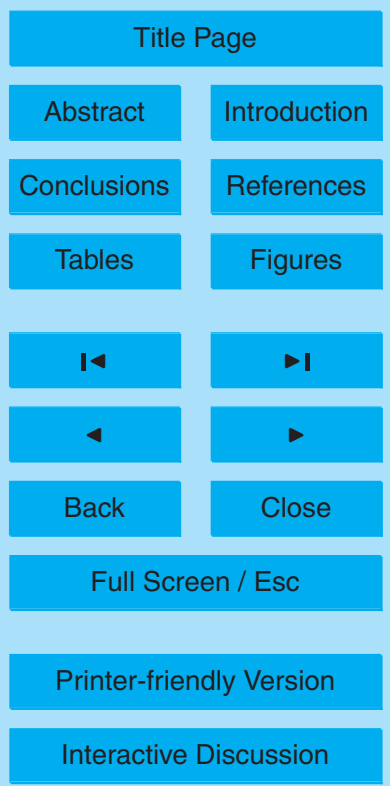


2. Clean continental aerosol (cc): remote, pollution free and continental airborne particles.

3. Urban aerosol (ua): high degree of anthropogenic pollution.

4. Clean maritime aerosol $(\mathrm{cm})$ : oceanic particles of remote maritime environments.

5. Maritime mineral aerosol $(\mathrm{mm})$ : particles of marine origin mix with desert aerosol.

6. Maritime polluted aerosol ( $\mathrm{mp}$ ): man-made particles from continental air masses, especially in heavily polluted regions and industrialized harbour areas, released in the marine atmosphere.

A power law function is used to fit D'Almeida et al. (1991)'s aerosol model data below:

$10 \quad \gamma=1+a \cdot \mathrm{RH}^{b}+c \cdot \mathrm{RH}^{d}$

Where $\mathrm{RH}$ is relative humidity (between 0 and 1 ) and $\gamma$ is the normalized extinction (ratio of scattering extinction coefficient of aerosol to scattering extinction coefficient of dry aerosol). The fitted curves and related parameters are summarized in Fig. 1 and Table 1, respectively. Equation 3 implies the highly nonlinear contribution of the hygroscopicity at high $\mathrm{RH}$.

Cheng et al. (2004) used a combination of shape function to simulate the effect of airborne particle mixture on extinction, which is based on D'Almeida et al. (1991)'s aerosol model. The fitted equation is in the form:

$$
Y(\mathrm{RH})=Y_{0}\left(a \gamma_{\mathrm{ac}}+b \gamma_{\mathrm{cc}}+c \gamma_{\mathrm{ua}}+d \gamma_{\mathrm{cm}}+e \gamma_{\mathrm{mm}}+f \gamma_{\mathrm{mp}}\right)
$$

Method II: $a+b+c+d+e+f=1$

$$
Y(\mathrm{RH})=\frac{\sigma(\mathrm{RH})}{\text { conc }_{\text {aerosol }}}, Y_{0}=\frac{\sigma(0)}{\text { conc } \cdot \text { aerosol }}
$$

Where $Y(\mathrm{RH})$ is the ratio of aerosol extinction coefficient $(\sigma)$ to aerosols concentration, $Y_{0}$ describes the same ratio with dry conditions, and $a, b, c, d, e$ and $f$ are the

\section{Determination of aerosol \\ hygroscopicity and composition}

C. H. Chan et al.

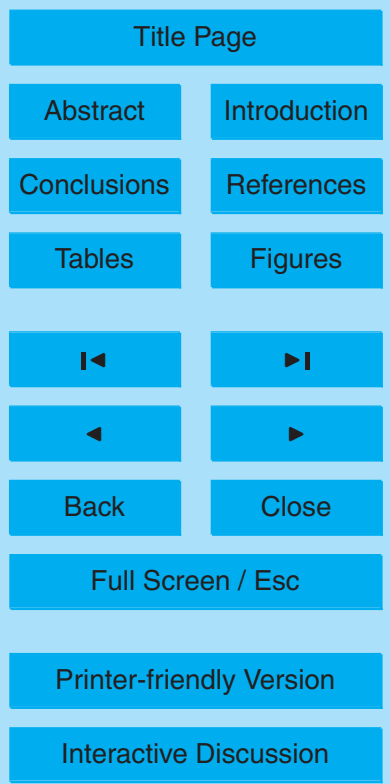


contributions from six aerosol components. Constraints are included to ensure the coefficients a to $f$ remain positive. Figure 1 indicates that maritime aerosols have their particular curves when the hygroscopicity of continental aerosols is very similar, which would advantage Method II to separate the aerosol into different groups (such as conti5 nental group and maritime group). In this paper, Nelder-Mead Simplex Method (Nelder et al., 1965) with bounding condition will be used to simulate the result.

In order to quantify the accuracy of the result of Sect. 4, the definition of root mean square error (RMSE) of $\chi$ is defined by:

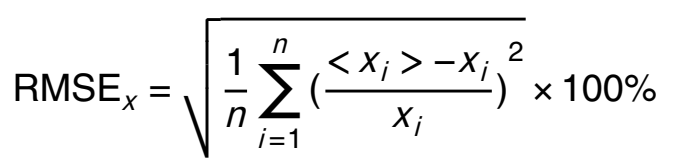

\section{Where $i=1,2, \ldots, n,<\chi_{i}>$ is used to denote the estima
will be used to denote the estimated value hereafter.}

After using Eq. (2) to calculate the dry extinction coefficient $\left(\sigma_{0}\right)$ with $\mathrm{RH}$ and extinction coefficient $(\sigma)$, the linear regression without intercept can be use to establish the linear relationship between the $\sigma_{0}$ and aerosol concentration.

$15<\sigma_{0}>=Y_{0} \times$ Concentration $_{\text {aerosol }}$

Where $\left\langle\sigma_{0}\right\rangle$ is the estimation of $\sigma_{0}, Y_{0}$ is the parameter extracted from the linear regression, Concentration ${ }_{\text {aerosol }}$ is the concentration of aerosol. The results will be discussed in Sect. 4.1.

After using Eq. (3) and Eq. (4) to establish the nonlinear relationship between $\mathrm{RH}$ and ${ }_{20} Y$ (the ratio of aerosol extinction coefficient to aerosols concentration), the estimation of $Y$ can be extracted from the humidity $(\mathrm{RH})$ by Eq. (7) below.

$<Y>=Y_{0}\left(a \gamma_{\mathrm{ac}}+b \gamma_{\mathrm{cc}}+c \gamma_{\mathrm{ua}}+d \gamma_{\mathrm{cm}}+e \gamma_{\mathrm{mm}}+f \gamma_{\mathrm{mp}}\right)$

Where $\langle Y\rangle$ is the estimation of $Y$ (the ratio of aerosol extinction coefficient to aerosols concentration), $Y_{0}, a, b, c, d, e, f$, are the parameters extracted from Method II. The results will be discussed in Sect. 4.2.

\section{Determination of aerosol \\ hygroscopicity and composition}

C. H. Chan et al.

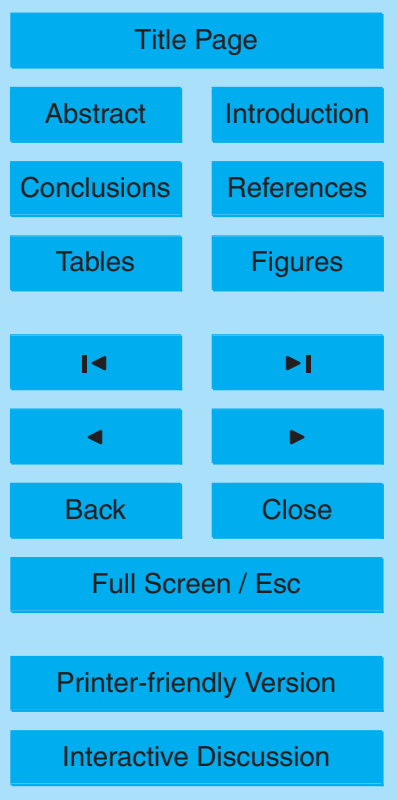

Interactive Discussion 
At the end, the RMSE is used to analyse the accuracy of results from Eq. (6) and Eq. (7). The assumption, in which the estimation of $\sigma_{0}\left(\left\langle\sigma_{0}\right\rangle\right)$ and $Y(\langle Y\rangle)$ is equal to ratio of the estimation of $\sigma(\langle\sigma\rangle)$ to function of $\mathrm{RH}$ and aerosols concentration, respectively, is made below.

5 Assumption: $\left\langle\sigma_{0}\right\rangle=\left\langle\frac{\sigma}{f(\mathrm{RH})}>=\frac{\langle\sigma\rangle}{f(\mathrm{RH})}\right.$

$$
\begin{aligned}
& <Y>=\left\langle\frac{\sigma}{\text { conc. }}>=\frac{\langle\sigma\rangle}{\text { conc. }}\right. \\
& \Rightarrow \text { RMSE }_{Y}=\sqrt{\frac{1}{n} \sum_{i=1}^{n}\left(\frac{\left\langle y_{i}\right\rangle-y_{i}}{y_{i}}\right)^{2}} \times 100 \% \\
& =\sqrt{\frac{1}{n} \sum_{i=1}^{n}\left(\frac{\left\langle\sigma_{i}\right\rangle}{\frac{\sigma_{i}}{\text { conc. }}-\frac{\sigma_{i}}{\text { conc. }}}\right)^{2} \times 100 \%}=\sqrt{\frac{1}{n} \sum_{i=1}^{n}\left(\frac{\left\langle\sigma_{i}>-\sigma_{i}\right.}{\sigma_{i}}\right)^{2}} \times 100 \%
\end{aligned}
$$$$
=\sqrt{\frac{1}{n} \sum_{i=1}^{n}\left(\frac{<\sigma_{0 i}>\times f(\mathrm{RH})-\sigma_{0 i} \times f(\mathrm{RH})}{\sigma_{0 i} \times f(\mathrm{RH})}\right)^{2}} \times 100 \%
$$

$$
=\sqrt{\frac{1}{n} \sum_{i=1}^{n}\left(\frac{<\sigma_{0 i}>-\sigma_{0 i}}{\sigma_{0 i}}\right)^{2}} \times 100 \%=\mathrm{RMSE}_{\sigma_{0}}
$$

(8)

It is shown in Eq. (8) that the accuracy between the result of Method I and II can be compared in next section.

\section{ACPD}

10, 23627-23656, 2010

\section{Determination of aerosol \\ hygroscopicity and composition}

C. H. Chan et al.

Title Page

Abstract

Introduction

Conclusions

References

Tables

Figures

14

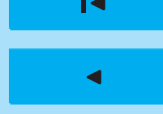

$\rightarrow 1$

Back

Close

Full Screen / Esc

Printer-friendly Version

Interactive Discussion 


\section{Results and discussions}

\subsection{Influence of the relative humidity on the aerosols extinction}

Naturally, aerosols extinction is expected to be linearly related to the concentration of aerosol. However, this relationship is affected by the humidity. The hygroscopic prop-

5 erties of aerosols are important because relative humidity can influence the aerosols extinction by changing the refractive index, and particle size distribution. Basically, the dry aerosol extinction coefficient $\left(\sigma_{0}\right)$ is proportional to the aerosols concentration. Figure $2 \mathrm{a}$ to $\mathrm{d}$ show the linear regression without intercept between aerosol extinction and PM concentration before and after considering the effect of relative humidity with 10 Method I modification, respectively. After this modification, the extinction coefficient can be seen to be more linearly related to PM concentration as expected (Fig. $2 \mathrm{c}$ to d). The linear relationship has an obvious improvement after modification, in which RMSE of dry aerosol extinction coefficient reduces over $10 \%$.

The whole data set was separated into 35 monthly groups. Figure 3 shows a monthly 15 variation of $Y_{0}$ (the ratios of $\sigma_{0}$ to concentration) from $0.0034 \mathrm{~m}^{3} /(\mu \mathrm{g} \mathrm{km})$ to 0.0062 and $0.0062 \mathrm{~m}^{3} /(\mu \mathrm{g} \mathrm{km})$ to $0.0104 \mathrm{~m}^{3} /(\mu \mathrm{g} \mathrm{km})$ for $\mathrm{PM}_{10}$ and $\mathrm{PM}_{2.5}$, respectively. This is around $20 \%$ of the annual $Y_{0}\left(0.0042\right.$ to $0.0049 \mathrm{~m}^{3} /(\mu \mathrm{g} \mathrm{km})$ and 0.0073 to $0.0084 \mathrm{~m}^{3}$ $/(\mu \mathrm{g} \mathrm{km})$ for $\mathrm{PM}_{10}$ and $\mathrm{PM}_{2.5}$, respectively). The $20 \%$ variation is very significant during high pollution periods. Thus, the effect should be considered when inverting the 20 PM concentration from the extinction coefficient measurement. In particular, this variability of $Y_{0}$ implies the relationship between the $\sigma_{0}$ and aerosol concentration may be influenced by other factors, which will be discussed and compared with the results of Method II in the next section. Two $Y_{0}$ values calculated from Method I related to $\mathrm{PM}_{10}$ and $\mathrm{PM}_{2.5}$ are shown in Fig. 3 , the curves of their time series are consistent overall.

25 Normally, aerosol samples do not have a constant ratio of $\mathrm{PM}_{10}$ and $\mathrm{PM}_{2.5}$. Thus, the small discrepancies of the trends of two curves are reasonable. In addition, the difference between the coarse and fine aerosol composition also accounts for part of the discrepancies.

\section{Determination of aerosol \\ hygroscopicity and composition}

C. H. Chan et al.

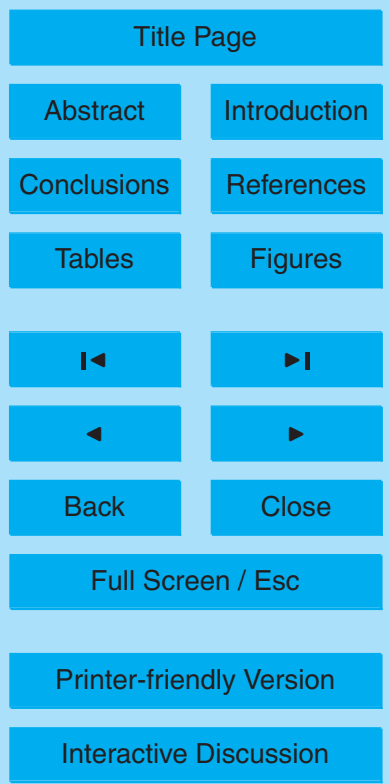




\subsection{Method II}

The significance of the influence of humidity on aerosols has been discussed in the previous section. The monthly variations and the cause will be discussed in this section.

5 Equation (8) shows that the RMSE of $\sigma_{0}$ in previous Sect. 4.1 can be compared with the RMSE of $Y$ in this Sect. 4.2. The reduction of RMSE of $Y$ in Method II shown in Fig. 4 indicates the improvement of accuracy of the simulation due to considering the effect of composition on hygroscopicity. In particular, this improvement is more significant during autumn and winter (except the case in June 2008). Comparing the

10 $Y_{0}$ calculated from Method I and Method II in Fig. 5, the $Y_{0}$ from Method I is in good agreement with the results from Method II. The small discrepancies are related to more accuracy of Method II due to considering the aerosol composition.

Table 2 shows the seasonal variation of the percentage of maritime aerosols at Hong Kong International Airport (Cheng et al., 2004). Basically, the tendency is higher in 15 summer and lower in winter, which coincides with the predominant monsoon pattern shown in Sect. 2 (dry northerly airflow from mainland is related to continental aerosols while wet southerly air mass is in connection with maritime particles). Figure 6 indicates that maritime aerosol is dominant in Macao especial during summer, which is consistent with the Hong Kong situation. Figure $7 \mathrm{a}$ to $\mathrm{c}$ shows the more contribution of maritime polluted aerosol especially during autumn and winter, which explains the reason why maritime aerosol is relative high during this period. It should be related to man-made particles from continental air masses. Furthermore, a relatively important contribution of maritime polluted aerosols is reasonable in the PRD situation (which is a very important industrialized region in Southern China). This monthly variation of the hygroscopicity due to different aerosol composition should be considered in future model simulation because the highly nonlinear relationship between $\mathrm{RH}$ and the aerosol mass extinction efficiency at high $\mathrm{RH}(>80 \%)$ must affect AOD simulation. The contribution of hygroscopicity related to aerosol composition should be considered in future aerosol concentration inversion with aerosol extinction measurement.

\section{Determination of aerosol hygroscopicity and composition}

C. H. Chan et al.

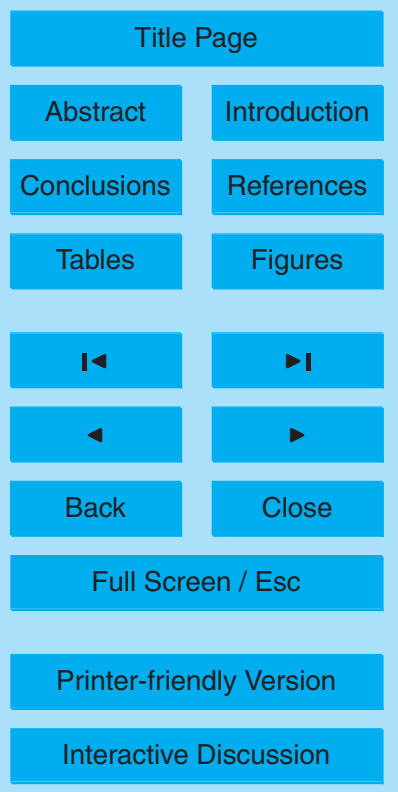




\section{Conclusions}

In the present study, the influence of relative humidity $(\mathrm{RH})$ and composition on aerosol scattering extinction in Macao at Pearl River Delta of China is investigated based on the hourly averaged observation of $\mathrm{RH}$, visibility and aerosol concentration. The 5 consistency of the estimated ratio $\left(Y_{0}\right)$ of dry aerosol extinction coefficient $\left(\sigma_{0}\right)$ to aerosol concentration between Hänel (1984) modification (Method I) and Cheng et al. (2004) method (Method II) proves the feasibility of the mathematic method to determine aerosol hygroscopicity. The monthly curve of the proportion of maritime aerosols of Macao calculated from Method II is in good agreement with the Asiatic Monsoon pattern and HKIA situation, when the relative high maritime aerosol is related to manmade particles from continental air masses (maritime polluted aerosol). Therefore, it is practical to use mathematic methods to estimate aerosol composition, which is one of the most important parameters during monitoring the aerosol optical properties by remote sensing (such as Lidar, MODIS, sun/star photometer, and etc.) and simulating aerosol forcing in a climate model, especially at high $\mathrm{RH}(>80 \%)$. The obvious temporal variability of $Y_{0}$ shall be considered in future when estimating the aerosol concentration with extinction coefficient by remote sensing as well. However, it is very difficult to use a statistic method to estimate the detail characteristics of the aerosol. A further in situ measurement of the chemical composition is still necessary to analyse the detail characteristic. In addition, remote sensing measurements and aerosol transportation models should also be used to reveal a more complete picture about the aerosol world.

Acknowledgements. This research was co-funded by Science and Technology Development Fund of Macao SAR. Reference number: 021/2007/A2 and Meteorological and Geophysical Bureau, Macao, China.

ACPD

10, 23627-23656, 2010

\section{Determination of aerosol \\ hygroscopicity and composition}

C. H. Chan et al.

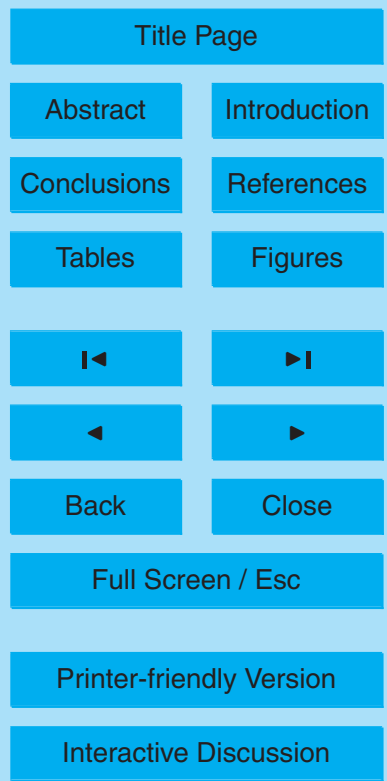




\section{References}

Anderson, T. L., Charlson, R. J., Schwartz, S. E., Knutti, R., Boucher, O., Rodhe, H., and Heintzenberg, J.: Climate forcing by aerosols - a hazy picture, Science, 300(5622), 11031104, 2003.

5 Baynard, T., Garland, R. M., Ravishankara, A. R., Tolbert, M. A., and Lovejoy, E. R.: Key factors influencing the relative humidity dependence of aerosol light scattering, Geophys. Res. Lett., 33, L06813, doi:10.1029/2005GL024898, 2006.

Bian, H., Chin, M., Rodriguez, J. M., Yu, H., Penner, J. E., and Strahan, S.: Sensitivity of aerosol optical thickness and aerosol direct radiative effect to relative humidity, Atmos. Chem. Phys.,

10 9, 2375-2386, doi:10.5194/acp-9-2375-2009, 2009.

Buzorius, G., Zelenyuk, A., Brechtel, F., and Imre, D.: Simultaneous determination of individual ambient particle size, hygroscopicity and composition, Geophys. Res. Lett., 29(20), 1974, doi:10.1029/2001GL014221, 2002.

Carrico, C. M., Kus, P., Rood, M. J., Quinn, P. K., and Bates, T. S.: Mixtures of pollution, dust, sea salt, and volcanic aerosol during ACE-Asia: Radiative properties as a function of relative humidity, J. Geophys. Res.-Atmos., 108(D23), 8650, doi:10.1029/2003JD003405, 2003.

Charlson, R. J., Schwartz, S. E., Hales, J. M., Cess, R. D., Coakley Jr., J. A., Hansen, J. E., and Hofmann, D. J.: Climate Forcing by Anthropogenic Aerosols, Science, 255(5043), 423-430, 1992.

Charlson, R. J., Seinfeld, J. H., Nenes, A., Kulmala, M., Laaksonen, A., and Facchini, M. C.: Atmospheric science - Reshaping the theory of cloud formation, Science, 292(5524), 20252026, 2001.

Cheng, A. Y. S., Walton, A., and Chan, R. L. M.: Aerosol Characteristics at the Hong Kong International Airport in 2003, Proceedings of SPIE, 5832, 164-171, 2004.

Covert, D. S., Charlson, R. J., and Ahlquist, N. C.: A Study of the Relationship of Chemical Composition and Humidity to Light Scattering by Aerosols, J. Appl. Meteorol., 11, 968-976, 1972.

D’Almeida, G. A., Koepke, P., and Shettle, E. P.: Atmospheric aerosols: global climatology and radiative characteristics, A. Deepak Publishing, Hampton, 1991.

30 Deng, X. J., Tie, X. X., Wu, D., Zhou, X. J., Bi, X. Y., Tan, H. B., Li, F., and Jiang, C. L.: Longterm trend of visibility and its characterizations in the Pearl River Delta (PRD) region, China, Atmos. Environ., 42(7), 1424-1435, 2008.

\section{Determination of aerosol \\ hygroscopicity and composition}

C. H. Chan et al.

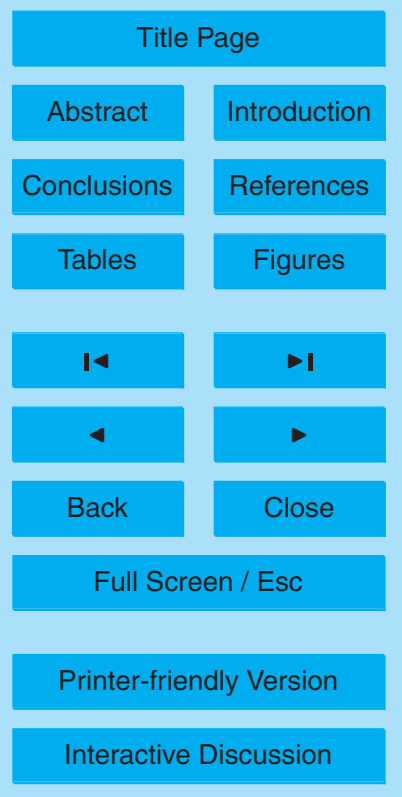

Interactive Discussion 
Eichler, H., Cheng, Y. F., Birmili, W., Nowak, A., Wiedensohler, A., Brüggemann, E., Gnauk, T., Herrmann, H., Althausen, D., Ansmann, A., Engelmann, R., Tesche, M., Wendisch, M., Zhang, Y. H., Hu, M., Liu, S., and Zeng, L. M.: Hygroscopic properties and extinction of aerosol particles at ambient relative humidity in South-Eastern China, Atmos. Environ., 5 42(25), 6321-6334, 2008.

Fan, J., Zhang, R., Tao, W. K., and Mohr, K. I.: Effects of aerosol optical properties on deep convective clouds and radiative forcing, J. Geophys. Res.-Atmos., 113, D08209, doi:10.1029/2007JD009257, 2008.

Hänel, G.: Parametrization of the Influence of Relative Humidity on Optical Aerosol Properties,

10 A. Deepak, Hampton, Virginia, 1984.

Hinkley, E. D.: Laser Monitoring of the Atmosphere: Springer-Verlag, New York, 1976.

Jones, T. A. and Christopher, S. A.: Statistical properties of aerosol-cloud-precipitation interactions in South America, Atmos. Chem. Phys., 10, 2287-2305, doi:10.5194/acp-10-22872010, 2010.

Kim, S. W., Yoon, S. C., Kim, J., and Kim, S. Y.: Seasonal and monthly variations of columnar aerosol optical properties over east Asia determined from multi-year MODIS, LIDAR, and AERONET Sun/sky radiometer measurements, Atmos. Environ., 41(8), 1634-1651, 2007.

Kondragunta, S., Lee, P., McQueen, J., Kittaka, C., Prados, A. I., Ciren, P., Laszlo, I., Pierce, R. B., Hoff, R., and Szykman, J. J.: Air quality forecast verification using satellite data, J. Appl. 20 Meteorol. Clim., 47(2), 425-442, 2008.

Li, C. C., Lau, A. K. H., Mao, J. T., and Chu, D. A.:Retrieval, Validation, and Application of the 1-km Aerosol Optical Depth From MODIS Measurements Over Hong Kong, IEEE T. Geosci. Remote, 43(11), 2650-2658, 2005.

Liu, X. G., Cheng, Y. F., Zhang, Y. H., Jung, J., Sugimoto, N., Chang, S. Y., Kim, Y. J., Fan, S. J., and Zeng, L. M.: Influences of relative humidity and particle chemical composition on aerosol scattering properties during the 2006 PRD campaign, Atmos. Environ., 42(7), 1525-1536, 2008.

Massling, A., Leinert, S., Wiedensohler, A., and Covert, D.: Hygroscopic growth of submicrometer and one-micrometer aerosol particles measured during ACE-Asia, Atmos.

$30 \quad$ Chem. Phys., 7, 3249-3259, doi:10.5194/acp-7-3249-2007, 2007.

Menon, S., Hansen, J., Nazarenko, L., and Luo, Y. F.: Climate effects of black carbon aerosols in China and India, Science, 297(5590), 2250-2253, 2002.

Molnár, A., Mészáros, E., Imre, K., and Rüll, A.: Trends in visibility over Hungary between 1996

\section{Determination of aerosol \\ hygroscopicity and composition}

C. H. Chan et al.

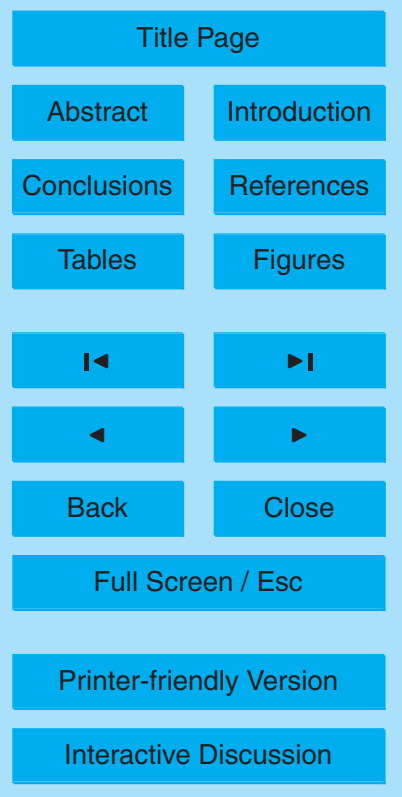


and 2002, Atmos. Environ., 42, 2621-2629, 2008.

Nelder, J. A. and Mead, R.: A Simplex-Method for Function Minimization, Comput. J., 7(4), 308-313, 1965.

Pilinis, C., Pandis, S. N., and Seinfeld, J. H.: Sensitivity of Direct Climate Forcing by Atmospheric Aerosols to Aerosol-Size and Composition, J. Geophys. Res.-Atmos., 100(D9), 18739-18754, 1995.

Ramanathan, V., Crutzen, P. J., Kiehl, J. T., and Rosenfeld, D.: Atmosphere - Aerosols, climate, and the hydrological cycle, Science, 294(5549), 2119-2124, 2001.

Rosenfeld, D., Dai, J., Yu, X., Yao, Z. Y., Xu, X. H., Yang, X., and Du, C. L.: Inverse relations between amounts of air pollution and orographic precipitation, Science, 315(5817), 13961398, 2007.

Schulz, M., Textor, C., Kinne, S., Balkanski, Y., Bauer, S., Berntsen, T., Berglen, T., Boucher, O., Dentener, F., Guibert, S., Isaksen, I. S. A., Iversen, T., Koch, D., Kirkevåg, A., Liu, X., Montanaro, V., Myhre, G., Penner, J. E., Pitari, G., Reddy, S., Seland, Ø., Stier, P., and Takemura, T.: Radiative forcing by aerosols as derived from the AeroCom present-day and pre-industrial simulations, Atmos. Chem. Phys., 6, 5225-5246, doi:10.5194/acp-6-5225-2006, 2006.

Suzuki, K., Nakajima, T., Satoh, M., Tomita, H., Takemura, T., Nakajima, T. Y., and Stephens, G. L.: Global cloud-system-resolving simulation of aerosol effect on warm clouds, Geophys. Res. Lett., 35, L19817, doi:10.1029/2008GL035449, 2008.

20 Tam, K. S., Lam, K. I., Chan, C. H., Viseu, A., and Cheng, A. Y. S.: Studies of urban aerosols in Macao using a horizontal Mie Lidar, J. Light Scattering, 20(4), 375-378, 2008.

Twomey, S.: Influence of Pollution on Shortwave Albedo of Clouds, J. Atmos. Sci., 34(7), 11491152, 1977.

Uhlig, E. M., Stettler, M., and Hoyningen-Huene, W. V.: Experimental studies on the variability of the extinction coefficient by different air masses, Atmos. Environ., 28(5), 811-814, 1994.

Wang, W., Ren, L. H., Zhang, Y. H., Chen, J. H., Liu, H. J., Bao, L. F., Fan, S. J., and Tang, D. G.: Aircraft measurements of gaseous pollutants and particulate matter over Pearl River Delta in China, Atmos. Environ., 42(25), 6187-6202, 2008.

Wu, D., Tie, X. X., Li, C. C., Ying, Z. M., Lau, A. K. H., Huang, J., Deng, X. J., and Bi, X. Y.: 30 An extremely low visibility event over the Guangzhou region: A case study, Atmos. Environ., 39(35), 6568-6577, 2005.

Yoon, S. C. and Kim, J.: Influences of relative humidity on aerosol optical properties and aerosol radiative forcing during ACE-Asia, Atmos. Environ., 40(23), 4328-4338, 2006.

\section{Determination of aerosol \\ hygroscopicity and composition}

C. H. Chan et al.

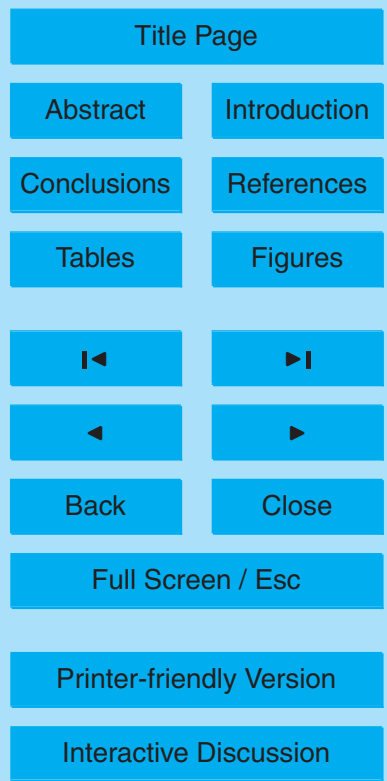




\section{ACPD}

10, 23627-23656, 2010

\section{Determination of aerosol \\ hygroscopicity and composition}

Table 1. Parameters of the six global aerosol types. The " $\gamma$ " is the normalized extinction (ratio of scattering extinction coefficient of aerosol to scattering extinction coefficient of dry aerosol). Subscript represents the six aerosol global types (including Average continental aerosol (ac), Clean continental aerosol (cc), Urban aerosol (ua), Clean maritime aerosol (cm), Maritime mineral aerosol (mm) and Maritime polluted aerosol (mp)). The "a", " $b$ ", " $c$ " and " $d$ " are the parameters in equation: $\gamma=1+a \cdot \mathrm{RH}^{b}+c \cdot \mathrm{RH}^{d}$.

\begin{tabular}{lrrrr}
\hline & $a$ & $b$ & $c$ & $d$ \\
\hline$\gamma_{\mathrm{ac}}$ & 4.08 & 122.85 & 2.89 & 8.59 \\
$\gamma_{\mathrm{cc}}$ & 4.24 & 115.13 & 2.88 & 8.30 \\
$\gamma_{\mathrm{ua}}$ & 4.45 & 122.92 & 2.86 & 8.43 \\
$\gamma_{\mathrm{cm}}$ & 24.67 & 81.20 & 9.19 & 6.40 \\
$\gamma_{\mathrm{mm}}$ & 1.32 & 83.92 & 0.23 & 4.44 \\
$\gamma_{\mathrm{mp}}$ & 11.68 & 93.71 & 4.68 & 6.79 \\
\hline
\end{tabular}

C. H. Chan et al.

Title Page

Abstract

Conclusions

Tables

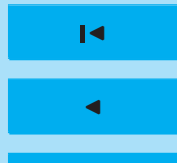

Back
Introduction

References

Figures

$>1$

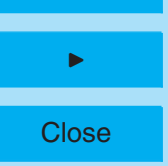

Full Screen / Esc

Printer-friendly Version

Interactive Discussion 


\section{ACPD}

10, 23627-23656, 2010

\section{Determination of aerosol \\ hygroscopicity and composition}

Table 2. Seasonal variations of aerosol components and $Y_{0}$ (the ratios of dry aerosol extinction coefficient to $\mathrm{PM}_{10}$ concentration, unit: $\left.\mathrm{m}^{3} /(\mu \mathrm{g} \mathrm{km})\right)$ at Hong Kong International Airport (HKIA, 2003; Cheng, 2004). The Cheng et al. (2004) method is used to inverse the percentage of Average continental aerosol (ac), Clean continental aerosol (cc), Urban aerosol (ua), Clean maritime aerosol $(\mathrm{cm})$, Maritime mineral aerosol $(\mathrm{mm})$ and Maritime polluted aerosol $(\mathrm{mp})$, respectively.

\begin{tabular}{|c|c|c|c|c|c|c|c|c|c|}
\hline & $Y_{0}$ & ac & $\mathrm{cc}$ & ua & $\mathrm{cm}$ & $\mathrm{mm}$ & $\mathrm{mp}$ & Continental & Maritime \\
\hline Whole Year & 0.0044 & $0.00 \%$ & $0.00 \%$ & $47.00 \%$ & $53.00 \%$ & $0.00 \%$ & $0.00 \%$ & & \\
\hline Spring $(3,4,5)$ & 0.0051 & $12.00 \%$ & $0.00 \%$ & $40.00 \%$ & $32.00 \%$ & $15.00 \%$ & $0.00 \%$ & $53.00 \%$ & \\
\hline Summer $(6,7,8)$ & 0.0057 & $0.00 \%$ & $0.00 \%$ & $0.00 \%$ & $21.00 \%$ & $79.00 \%$ & $0.00 \%$ & & 10 \\
\hline Autumn $(9,10,11)$ & 0.0038 & $20.00 \%$ & $0.00 \%$ & $11.00 \%$ & $53.00 \%$ & $0.00 \%$ & $16.00 \%$ & $\%$ & $0 \%$ \\
\hline Winter $(12,1,2)$ & 0.0052 & $40.00 \%$ & $0.00 \%$ & $25.00 \%$ & $35.00 \%$ & $0.00 \%$ & $0.00 \%$ & $65.00 \%$ & $35.00 \%$ \\
\hline
\end{tabular}

C. H. Chan et al.

Title Page

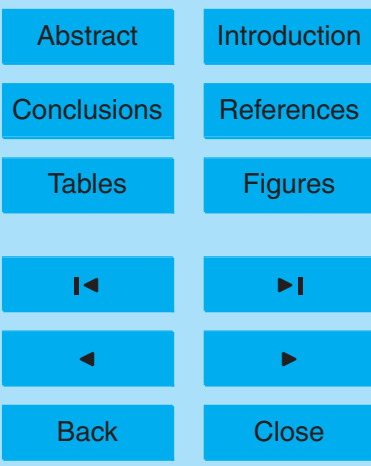

Full Screen / Esc

Printer-friendly Version

Interactive Discussion 


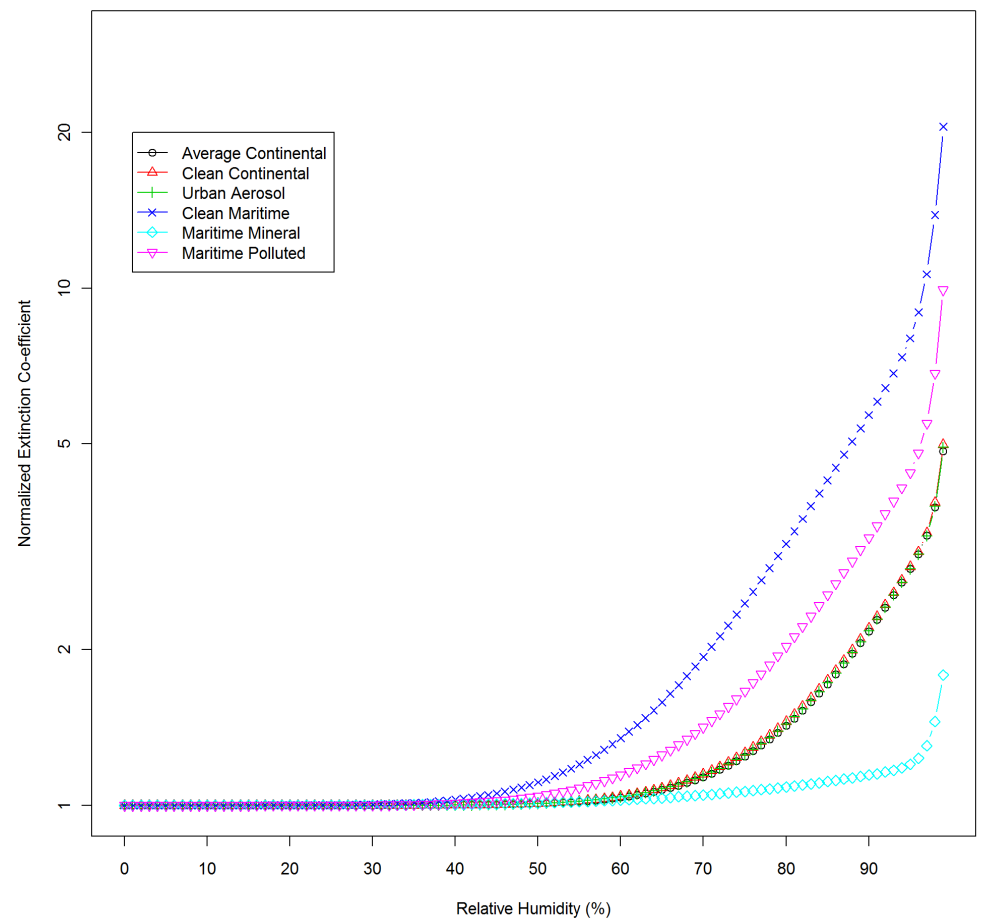

\section{ACPD}

10, 23627-23656, 2010

\section{Determination of aerosol \\ hygroscopicity and composition}

C. H. Chan et al.

Title Page

Abstract

Conclusions

Tables

14

4

Back

Full Screen / Esc

Printer-friendly Version

Interactive Discussion 


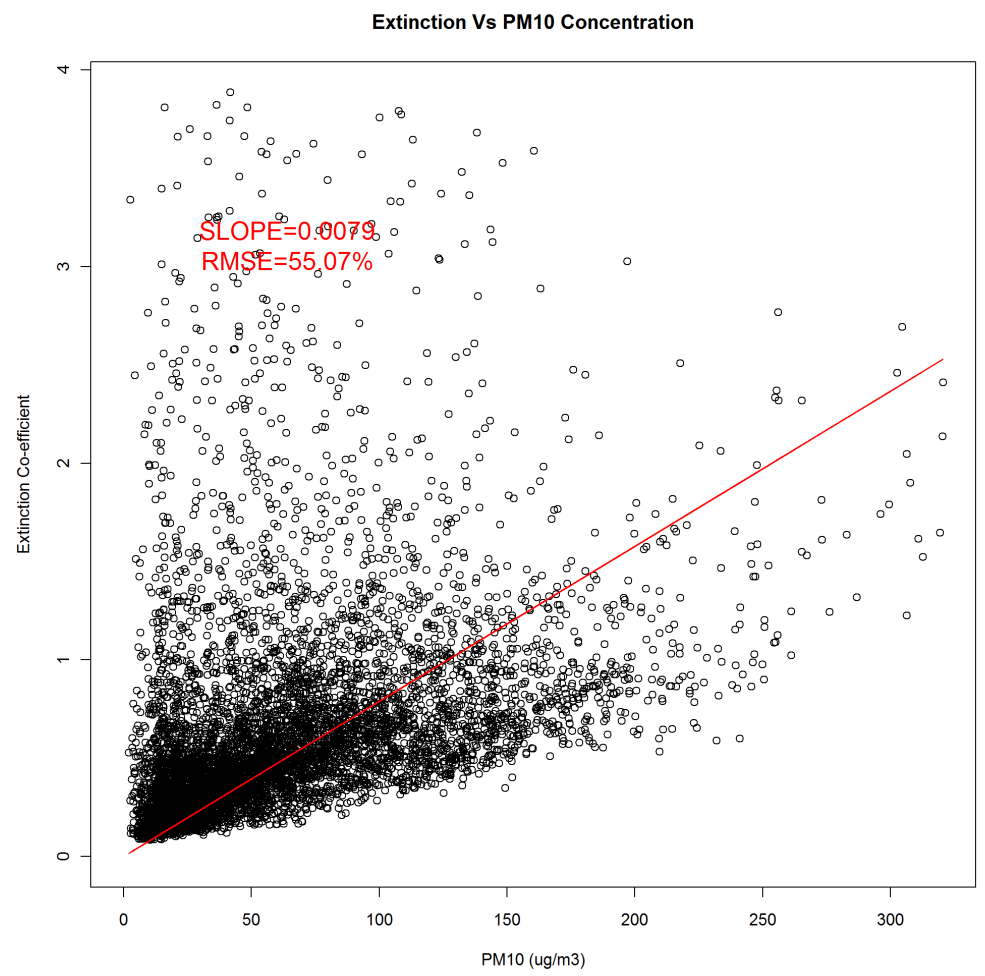

\section{ACPD}

10, 23627-23656, 2010

\section{Determination of aerosol \\ hygroscopicity and composition}

C. H. Chan et al.

Fig. 2a. The $\mathrm{PM}_{10}$ concentrations vs. aerosol extinction coefficient $\sigma$ (without Method I modification) in 2006, RMSE: $55.07 \%$.

Title Page

Abstract

Introduction

Conclusions

References

Tables

Figures

14

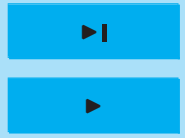

Back

Close

Full Screen / Esc

Printer-friendly Version

Interactive Discussion 


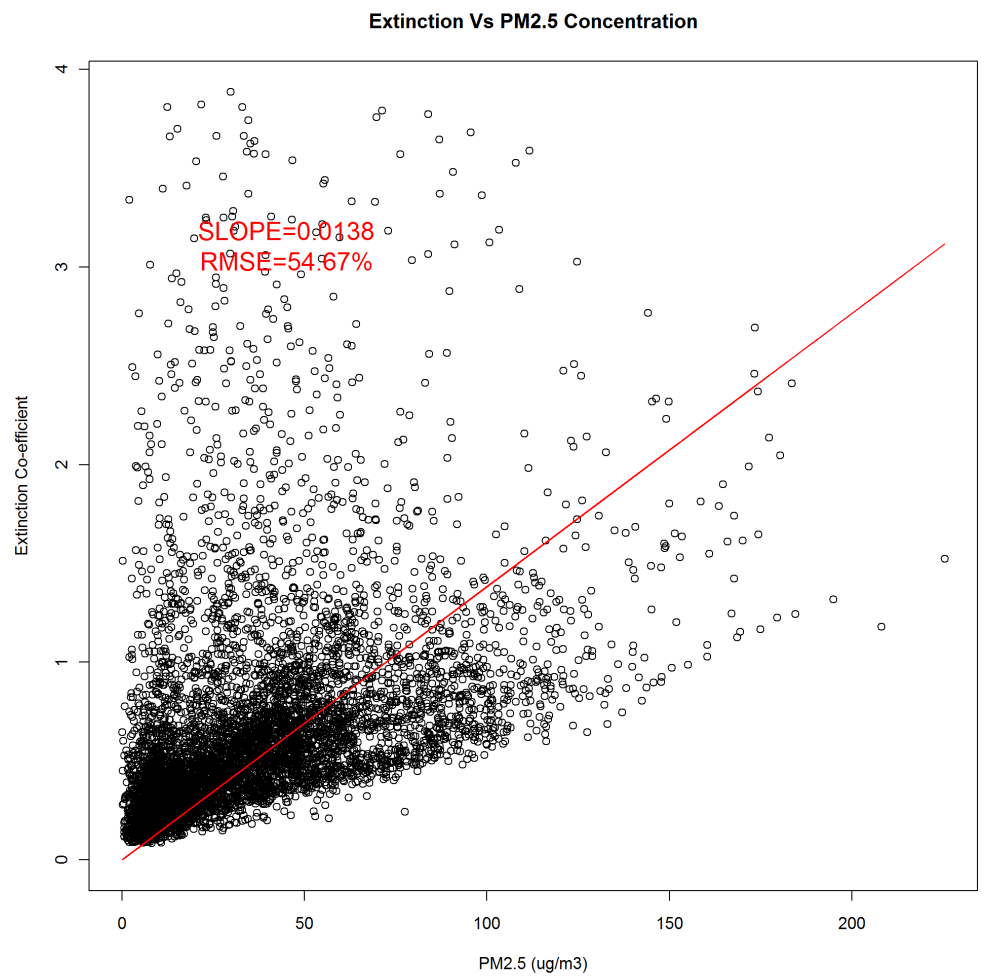

Fig. 2b. The $\mathrm{PM}_{2.5}$ concentrations vs. aerosol extinction coefficient $\sigma$ (without Method I modification) in 2006, RMSE: $54.67 \%$.

\section{ACPD}

10, 23627-23656, 2010

\section{Determination of aerosol \\ hygroscopicity and composition}

C. H. Chan et al.

Title Page

Abstract

Introduction

Conclusions

References

Tables

Figures

14

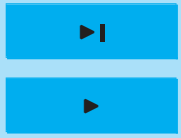

Back

Close

\section{Full Screen / Esc}

Printer-friendly Version

Interactive Discussion 


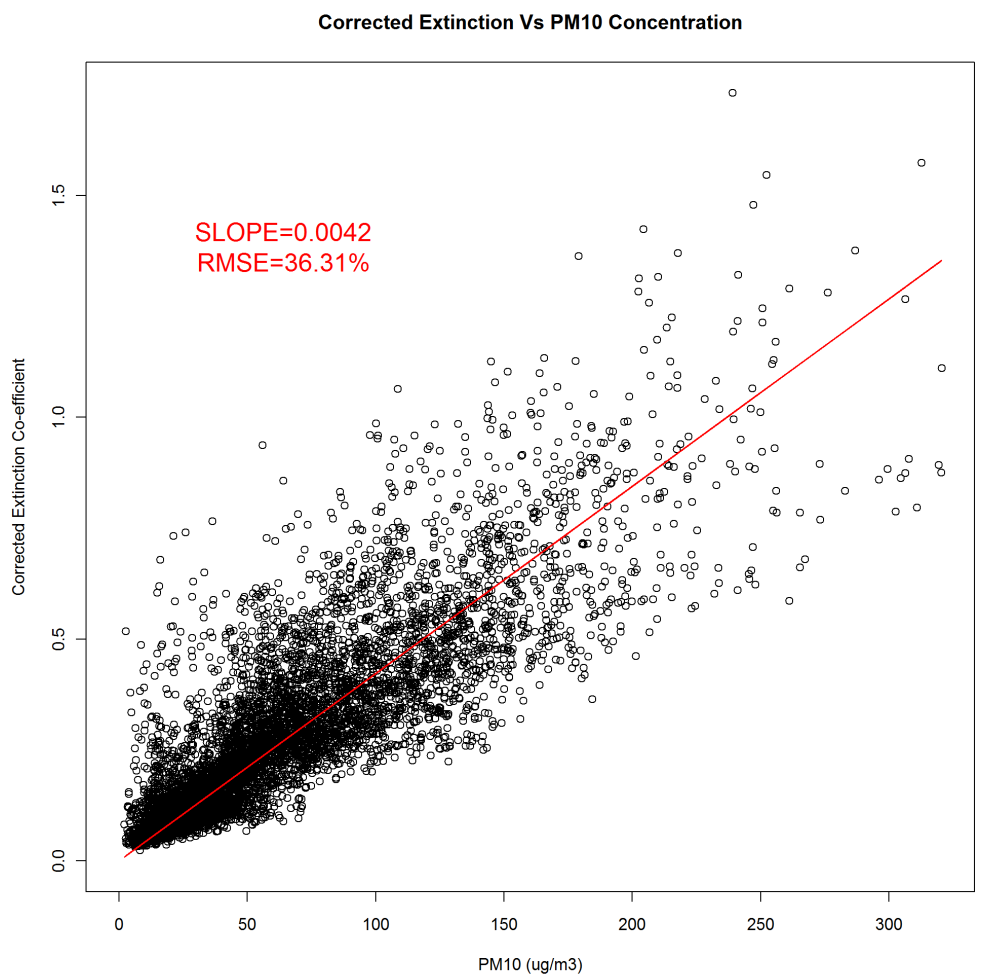

\section{ACPD}

10, 23627-23656, 2010

\section{Determination of aerosol \\ hygroscopicity and composition}
C. H. Chan et al.

\section{Title Page}

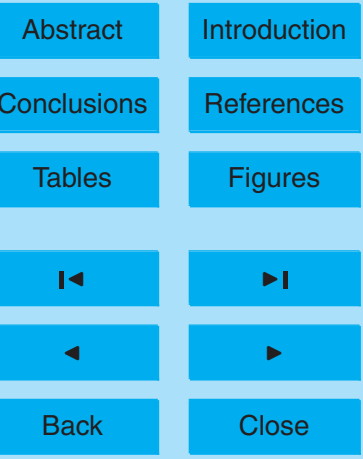

Full Screen / Esc

Fig. 2c. The $\mathrm{PM}_{10}$ concentrations vs. dry aerosol extinction coefficient $\sigma_{0}$ (with Method I modification) in 2006, RMSE: $36.31 \%$.

Printer-friendly Version

Interactive Discussion 


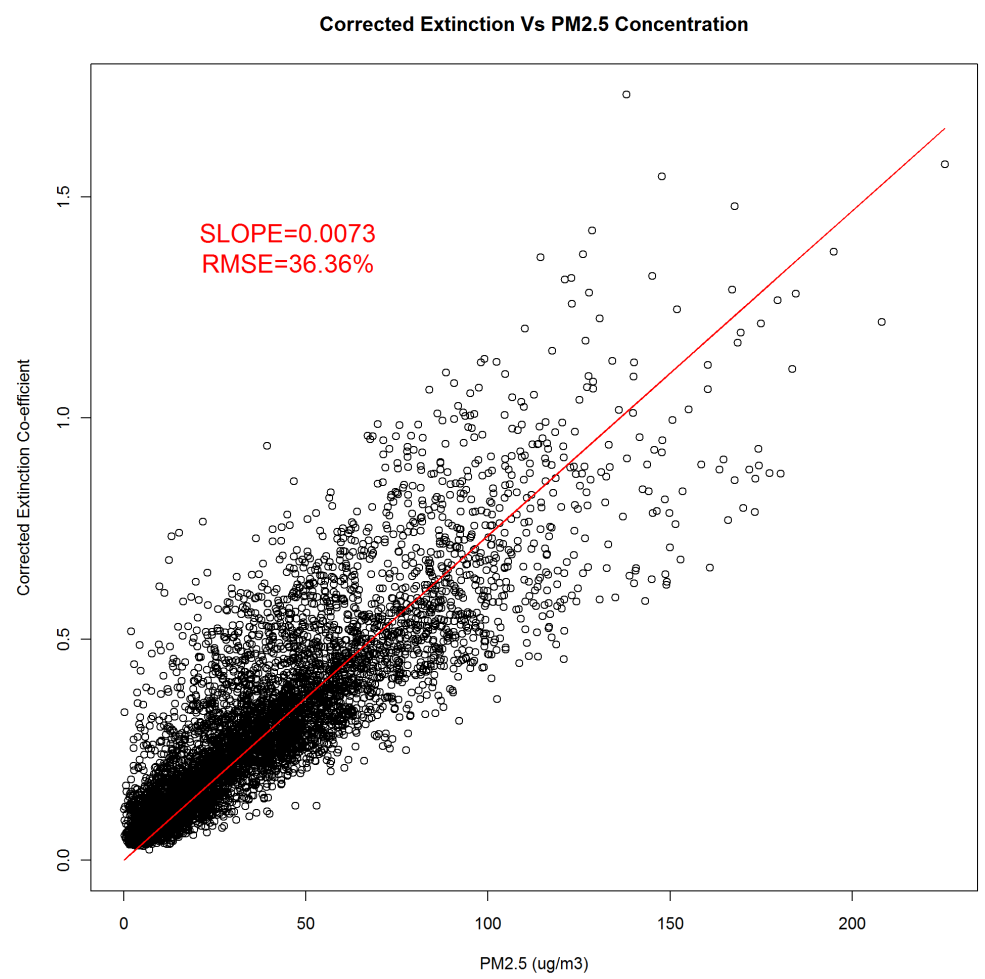

\section{ACPD}

10, 23627-23656, 2010

\section{Determination of aerosol \\ hygroscopicity and composition}
C. H. Chan et al.

\section{Title Page}

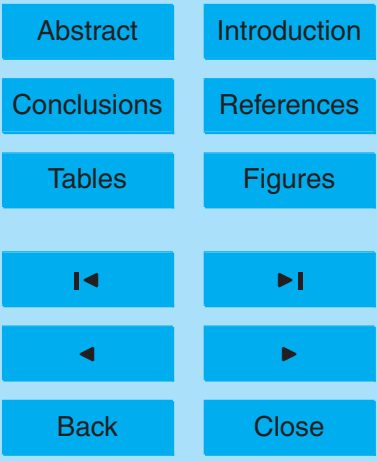

Full Screen / Esc

Fig. 2d. The $\mathrm{PM}_{25}$ concentrations vs. dry aerosol extinction coefficient $\sigma_{0}$ (with Method I modification) in 2006, RMSE: $36.36 \%$.

Printer-friendly Version

Interactive Discussion

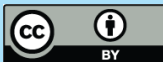




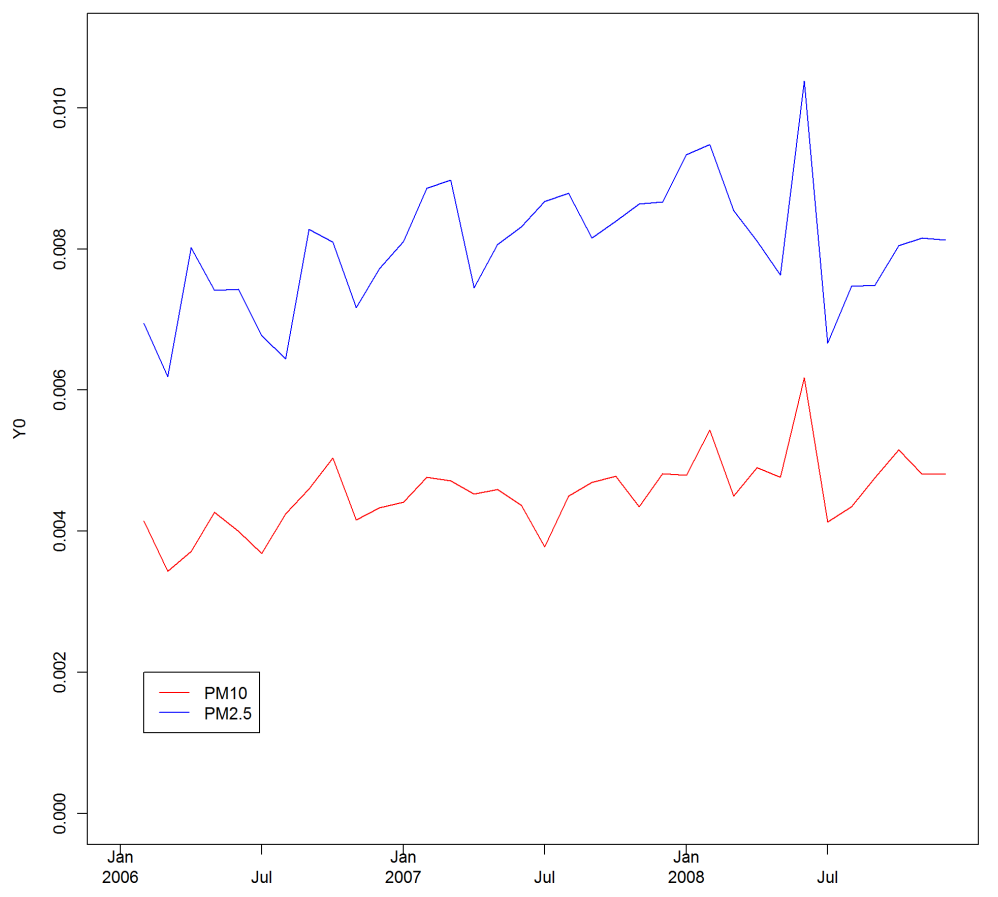

10, 23627-23656, 2010

\section{Determination of aerosol \\ hygroscopicity and composition}

C. H. Chan et al.

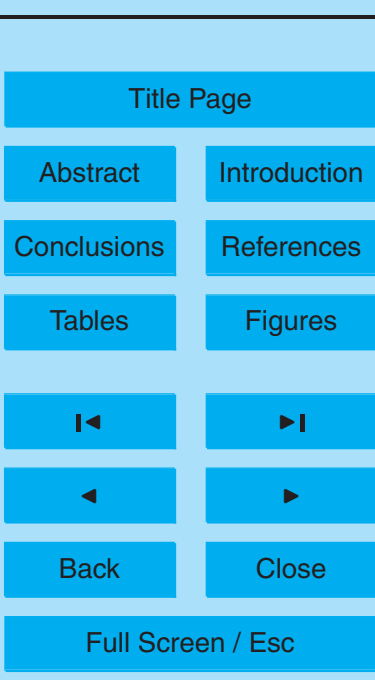

(unit: $\mathrm{m}^{3} /(\mu \mathrm{g} \mathrm{km})$ ), in which dry aerosol extinction is calculated from Method I. Red and blue represent $\mathrm{PM}_{10}$ and $\mathrm{PM}_{2.5}$, respectively.

Printer-friendly Version

Interactive Discussion 


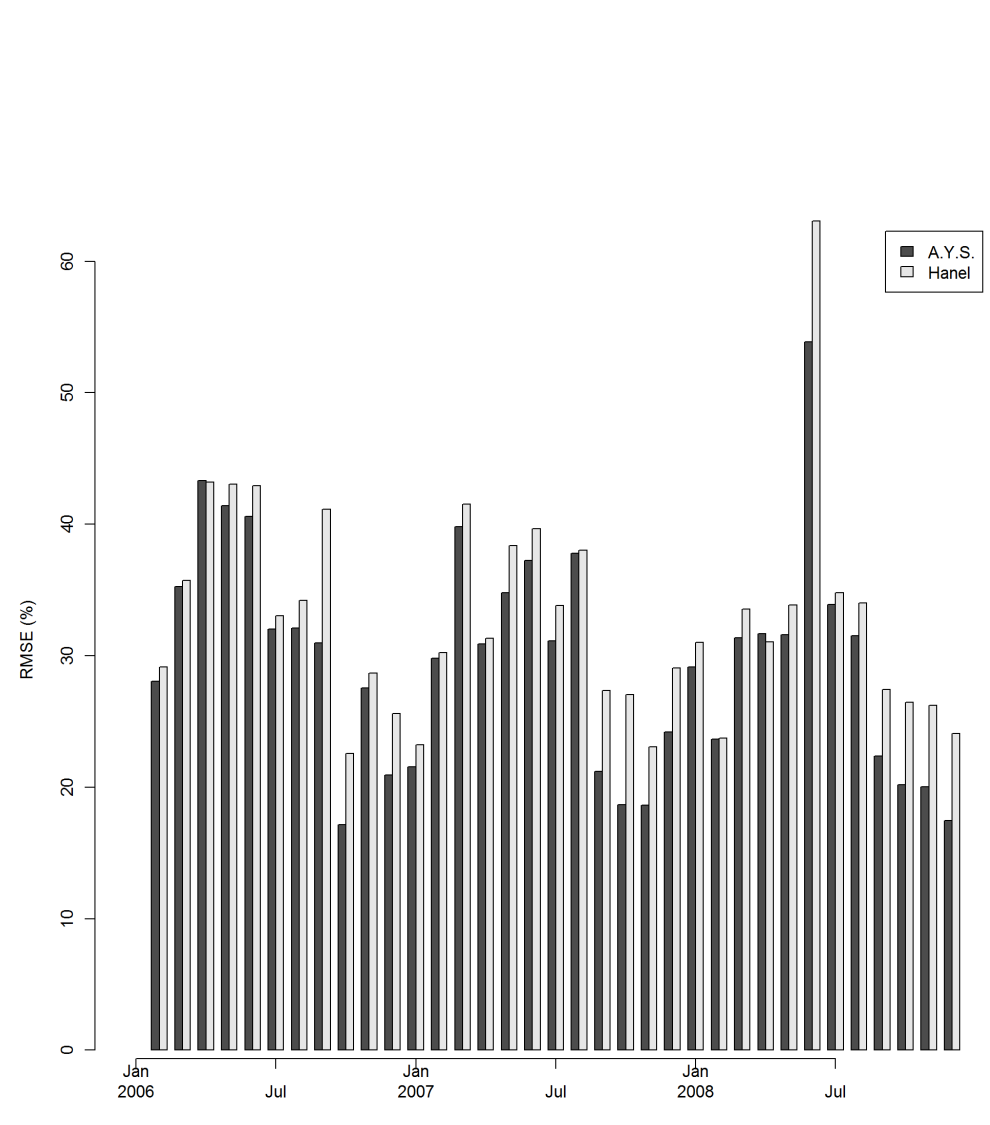

ACPD

10, 23627-23656, 2010

\section{Determination of aerosol}

hygroscopicity and composition

C. H. Chan et al.

Fig. 4. Root mean square error (RMSE) related to Method I (Hänel) in Grey and Method II (A.Y.S.) in black, respectively.

Title Page

Abstract Introduction

Conclusions References

14

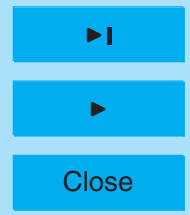

Back

Full Screen / Esc

Printer-friendly Version

Interactive Discussion 


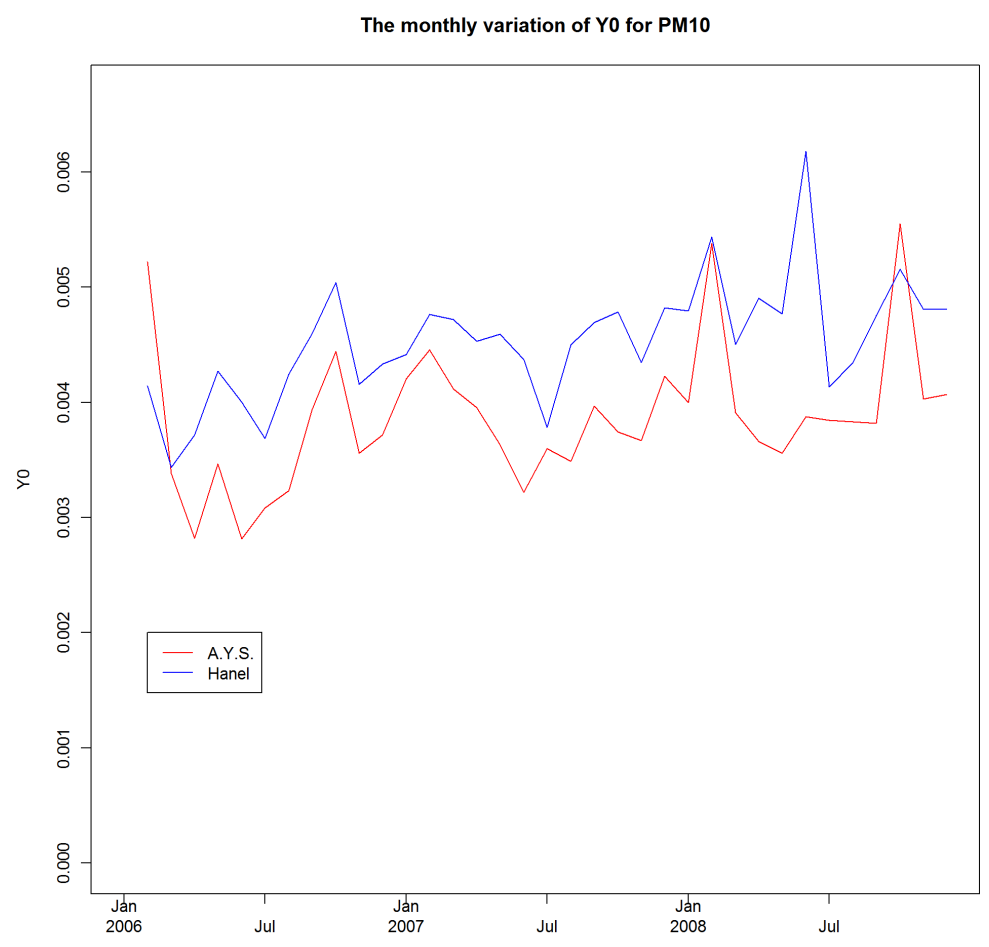

ACPD

10, 23627-23656, 2010
Determination of aerosol

hygroscopicity and composition

C. H. Chan et al.

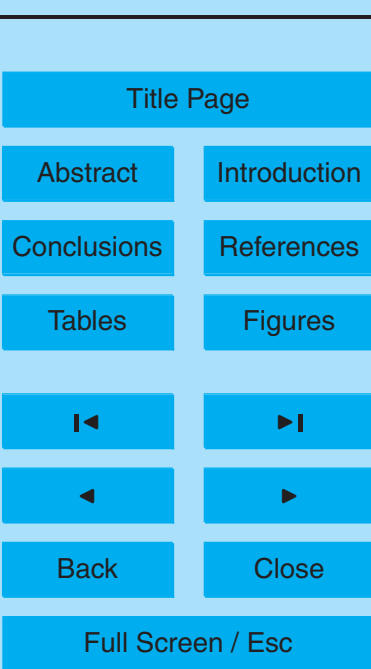

Fig. 5. The monthly variation of the ratio of dry aerosol extinction to aerosol $\left(\mathrm{PM}_{10}\right)$ concentrations $\left(Y_{0}\right.$, unit: $\left.\mathrm{m}^{3} /(\mu \mathrm{g} \mathrm{km})\right)$. Blue and red lines calculated from Method I(Hänel) and Method II (A.Y.S.), respectively.

Printer-friendly Version

Interactive Discussion 


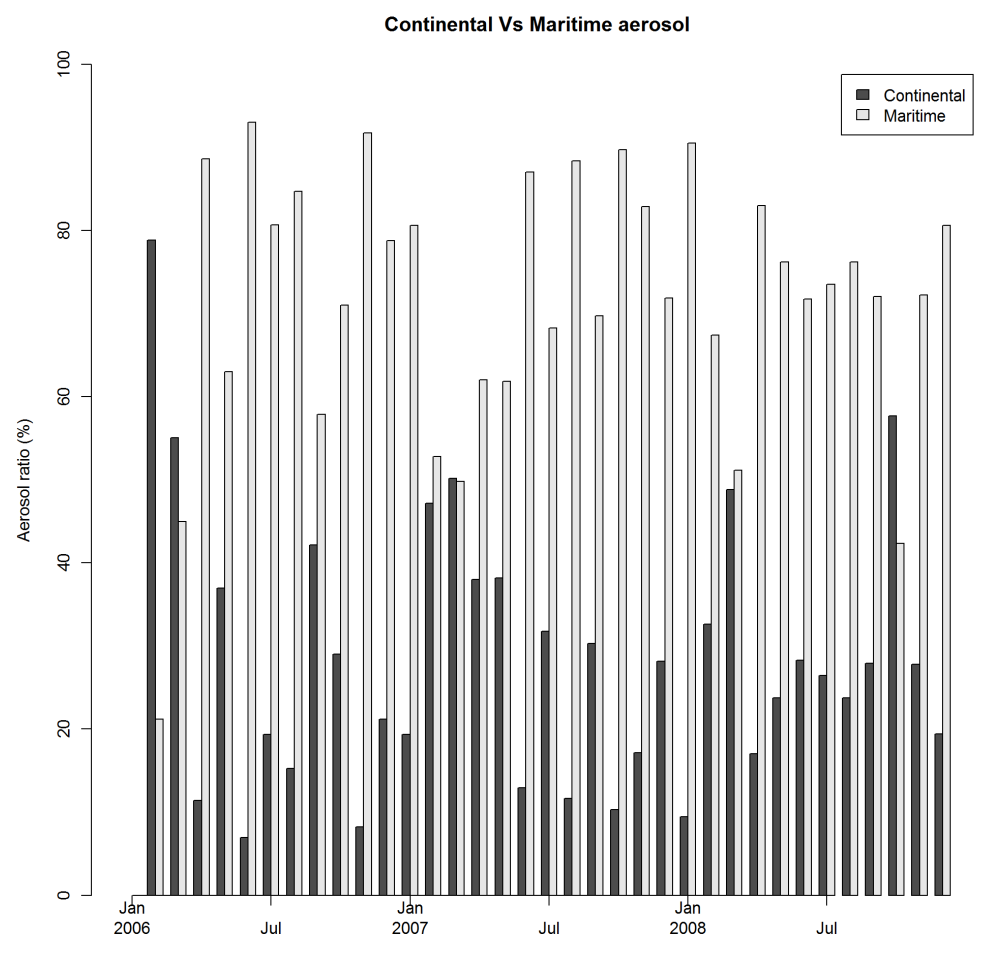

\section{ACPD}

10, 23627-23656, 2010

\section{Determination of aerosol \\ hygroscopicity and composition}

C. H. Chan et al.

Title Page

Abstract

Conclusions

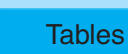

14

4

Back
Introduction

References

Figures

$\rightarrow$

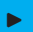

Close

Fig. 6. The Monthly variation of the percentage of Continental (in black) and Maritime (in grey) aerosols, respectively. The result is calculated from Method II with $\mathrm{PM}_{10}$. Continental aerosols include Average continental aerosol (ac), Clean continental aerosol (cc) and Urban aerosol (ua); Maritime aerosols include Clean maritime aerosol $(\mathrm{cm})$, Maritime mineral aerosol $(\mathrm{mm})$ and Maritime polluted aerosol ( $\mathrm{mp}$ ).

\section{Full Screen / Esc}

Printer-friendly Version

Interactive Discussion 


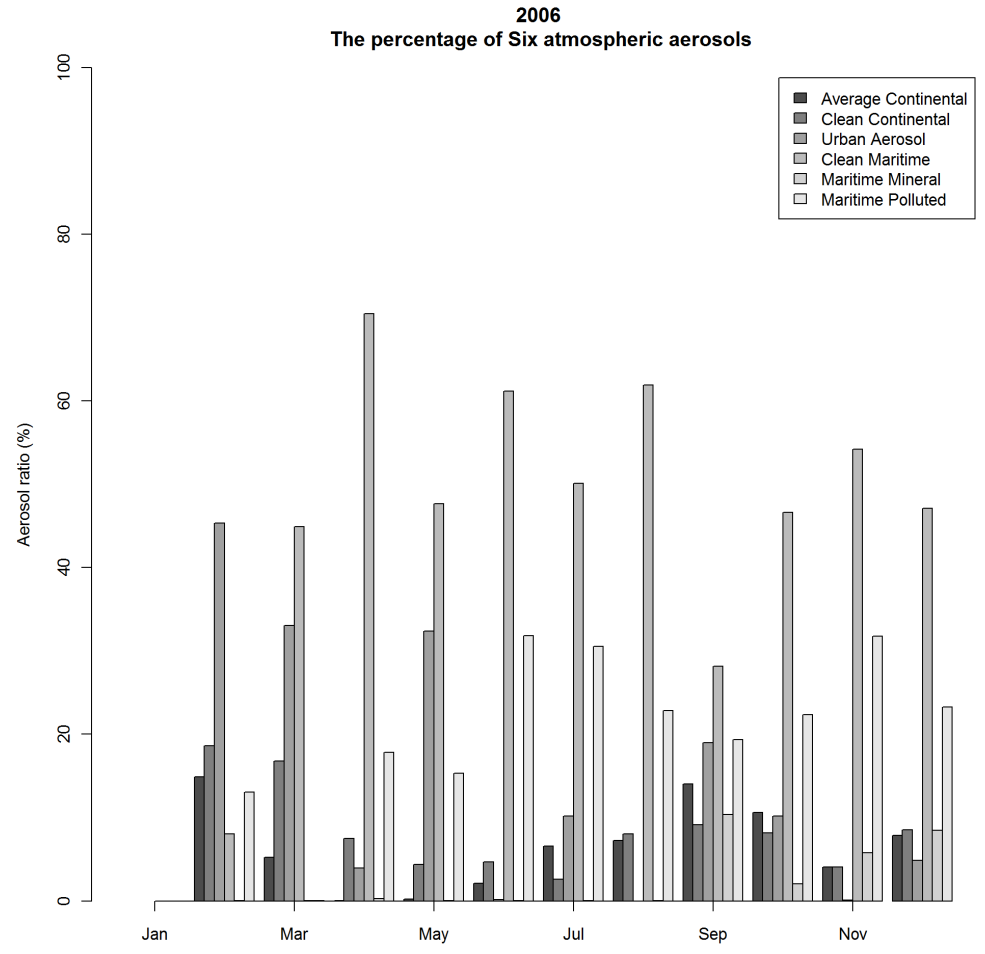

10, 23627-23656, 2010

\section{Determination of aerosol \\ hygroscopicity and composition}

C. H. Chan et al.

\section{Title Page}

Abstract

Conclusions

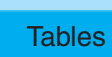

14

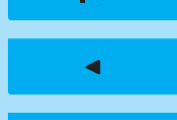

Back
Introduction

References

Figures

$>1$

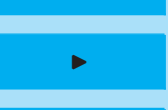

Close

Fig. 7a. The Monthly variation of the percentage of six atmospheric aerosols, include Average continental aerosol (ac), Clean continental aerosol (cc), Urban aerosol (ua), Clean maritime aerosol $(\mathrm{cm})$, Maritime mineral aerosol $(\mathrm{mm})$ and Maritime polluted aerosol $(\mathrm{mp}$ ) (in black to light grey) in 2006. The result is calculated from Method II with $\mathrm{PM}_{10}$.

\section{Full Screen / Esc}

Printer-friendly Version

Interactive Discussion 
2007

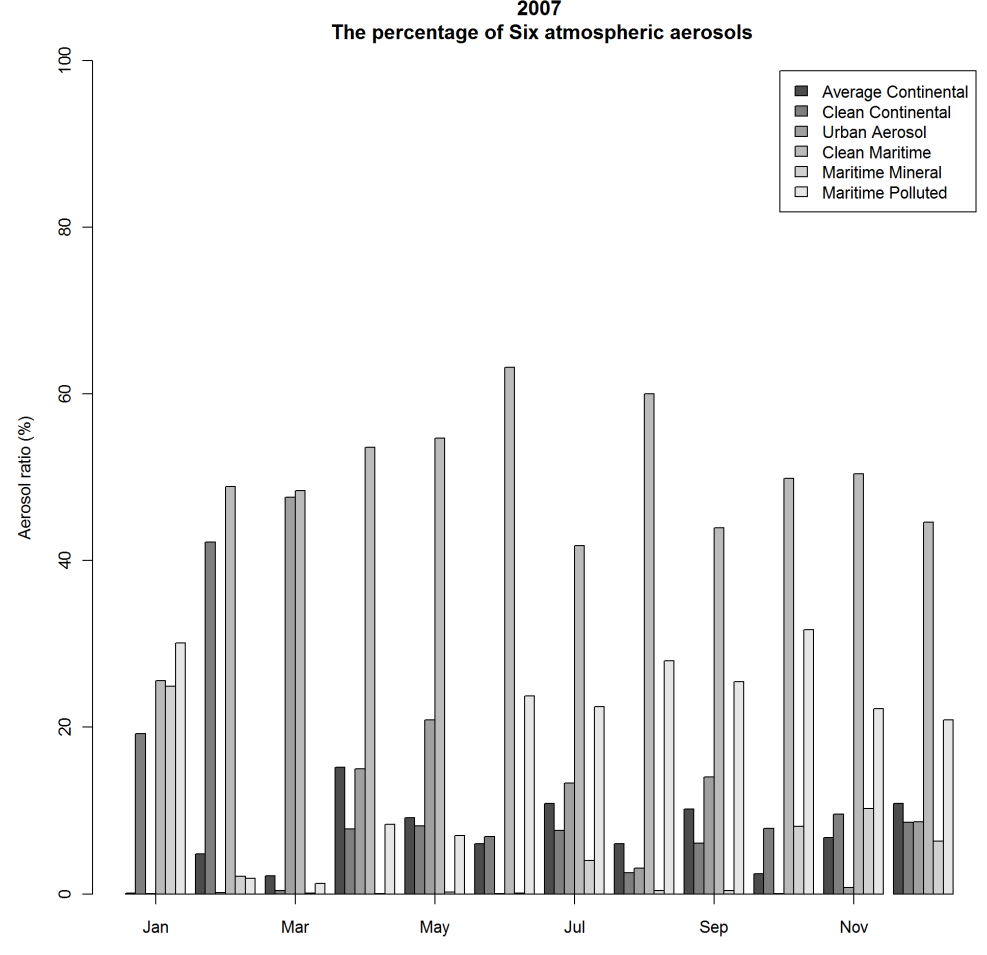

Fig. 7b. The Monthly variation of the percentage of six atmospheric aerosols, include Average continental aerosol (ac), Clean continental aerosol (cc), Urban aerosol (ua), Clean maritime aerosol $(\mathrm{cm})$, Maritime mineral aerosol $(\mathrm{mm})$ and Maritime polluted aerosol $(\mathrm{mp}$ ) (in black to light grey) in 2007. The result is calculated from Method II with $\mathrm{PM}_{10}$.

\section{ACPD}

10, 23627-23656, 2010

\section{Determination of aerosol \\ hygroscopicity and composition}

C. H. Chan et al.

Title Page

Abstract

Introduction

Conclusions

References

Tables

Figures

14

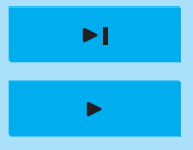

4

Back

Close

Full Screen / Esc

Printer-friendly Version

Interactive Discussion 


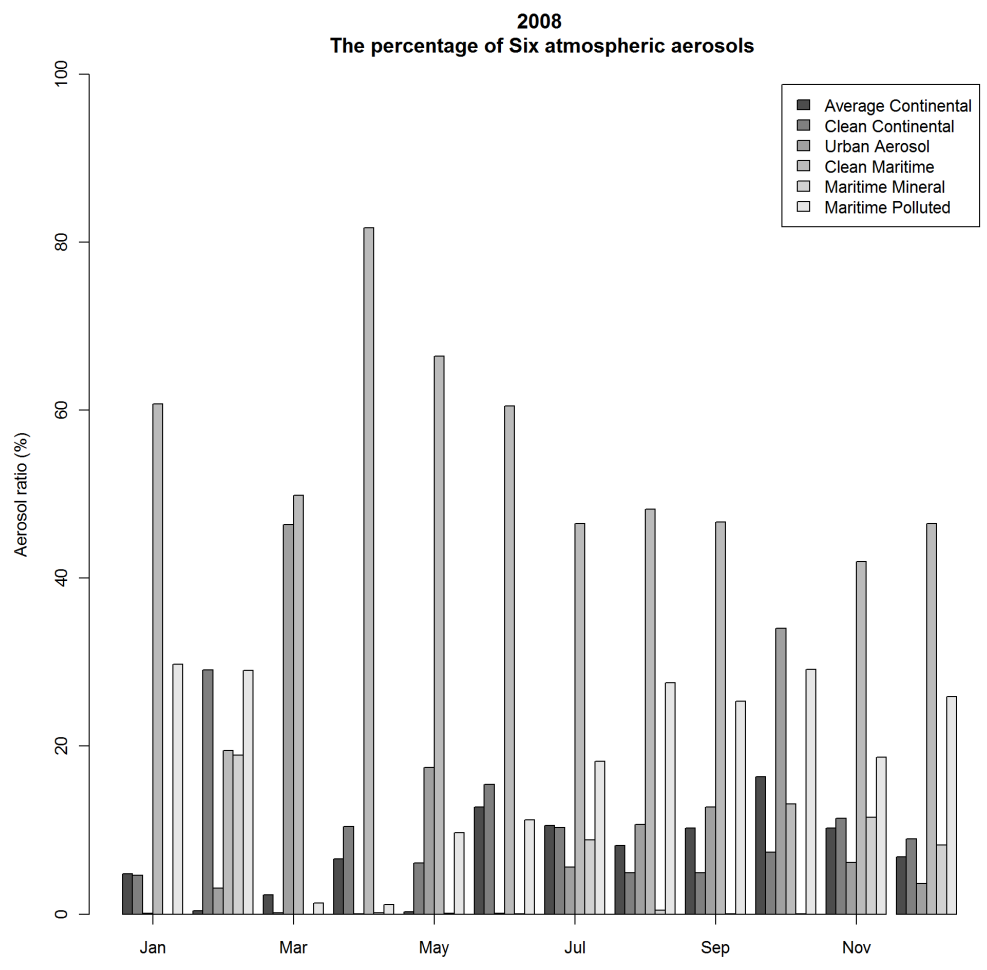

10, 23627-23656, 2010

\section{Determination of aerosol \\ hygroscopicity and composition}

C. H. Chan et al.

\section{Title Page}

\section{Abstract}

Conclusions

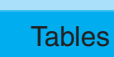

14

4

Back
Introduction

References

Figures

$>1$

$>$

Close

Fig. 7c. The Monthly variation of the percentage of six atmospheric aerosols, include Average continental aerosol (ac), Clean continental aerosol (cc), Urban aerosol (ua), Clean maritime aerosol $(\mathrm{cm})$, Maritime mineral aerosol $(\mathrm{mm})$ and Maritime polluted aerosol $(\mathrm{mp}$ ) (in black to light grey) in 2008. The result is calculated from Method II with $\mathrm{PM}_{10}$.

\section{Full Screen / Esc}

Printer-friendly Version

Interactive Discussion 